R E V I E W

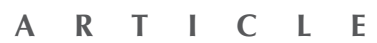

\title{
Perioperative antithrombotic management in joint replacement surgeries
}

HL Lee 李顯倫

KY Chiu 曲廣運

KH Yiu 姚啟恒

FY Ng 吳富源

CH Yan 忻振凱

PK Chan 陳秉強
Key words

Arthroplasty, replacement, hip; Arthroplasty, replacement, knee; Heart diseases; Heparin, low-molecular-weight; Venous thromboembolism

Hong Kong Med J 2013;19:531-8 DOI: $10.12809 / \mathrm{hkmj} 134073$

Queen Mary Hospital, The University of Hong Kong, Pokfulam, Hong Kong: Department of Orthopaedics and

Traumatology

HL Lee, MB, BS

KY Chiu, FHKCOS, FHKAM (Orthopaedic Surgery)

FY Ng, FHKCOS, FHKAM (Orthopaedic Surgery) CH Yan, FHKCOS, FHKAM (Orthopaedic Surgery) PK Chan, FHKCOS, FHKAM (Orthopaedic Surgery) Division of Cardiology, Department of Medicine KH Yiu, FHKCP, FHKAM (Medicine)

Correspondence to: Dr HL Lee Email: ricklhl@gmail.com
Objectives To determine optimal perioperative antithrombotic management for patients with cardiac diseases undergoing joint replacement surgeries.

Data sources MEDLINE and PubMed database search up to January 2013.

Study selection Those dealing with perioperative antithrombotic management of patients undergoing orthopaedic operations, especially joint replacement, and also those undergoing general surgery. Various combinations of the following key words were used in our search: "antiplatelet", "antithrombotic", "anticoagulant", "coronary stent", "perioperative", "venous thromboembolism", "cardiovascular", "surgery", "orthopaedic", "knee replacement", "hip replacement", "joint replacement", and "arthroplasty".

Data extraction Literature review, original articles, and best practice guidelines.

Data synthesis Patients should be stratified according to their risk of developing arterial thromboembolism in order to decide the most appropriate perioperative antiplatelet or anticoagulant regimen for them. After recent coronary stenting, including bare-metal stents implanted within 6 weeks and drug-eluting stents implanted within 6 months, surgery should be deferred. For venous thromboembolism prophylaxis in patients already on aspirin, the dosage should be adjusted as necessary or additional low-molecular-weight heparin administered.

Conclusion The perioperative management of patients with cardiac diseases in receipt of antithrombotic agents is based upon a delicate balance between the perceived risk of arterial thromboembolism and the perceived risk of perioperative bleeding. One must exercise good judgement in deciding the most appropriate perioperative antithrombotic regimen. Venous thromboembolism is also a common problem after joint replacement surgeries. For patients already on aspirin, optimal venous thromboembolism prophylaxis is still being debated.

\section{Introduction}

Joint replacement surgeries are a cost-effective measure to treat end-stage arthritis. ${ }^{1}$ Nowadays, it is common for patients with cardiac diseases on antithrombotic therapy to undergo joint replacement surgeries. This is partly due to the ageing population and increasingly sedentary lifestyle of most patients. Moreover, obesity itself is a common risk factor for the development of both coronary heart disease and degenerative arthritis. ${ }^{2}$

In Queen Mary Hospital, during the period from January 2012 to December 2012, a total of 324 patients underwent elective primary total knee or total hip replacement surgeries. Among these patients, 52 (16\%) were on some form of antithrombotic treatment. Of these 52 patients, $46(88 \%)$ were on aspirin, two $(4 \%)$ on warfarin, one $(2 \%)$ on clopidogrel, one ( $2 \%$ ) on low-molecular-weight heparin ( $\mathrm{LMWH})$, and two $(4 \%)$ on dual antiplatelet therapy.

These patients pose a perioperative management dilemma to orthopaedic surgeons. On the one hand, there is concern about the increased risk of perioperative bleeding associated with continuing antithrombotic therapy. ${ }^{3-5}$ On the other hand, there is concern about the risk of arterial thromboembolism (ATE) that may manifest as an acute coronary syndrome (ACS) and/or stroke due to discontinuing these agents. ${ }^{6}$

Venous thromboembolism (VTE) is also a common problem after joint replacement 


\section{關節置換手術前後抗血栓藥物的調校方案}

目的 探討因心藏系統疾病須服食抗血栓藥物而將接受關節 置換手術的病人, 其手術前後的最佳抗血栓藥物調校 方案。

資料來源 於MEDLINE及PubMed資料庫搜索直至2013年1月的 文獻。

研究選取 所有與手術前後抗血栓藥物調校方案相關的文獻, 包括將接受骨科手術, 尤其是關節置換手術的有關 病人, 以及將接受普通外科手術的有關病人。用 以搜索文獻的不同組合的關鍵詞為「抗血小板」 (antiplatelet)、「抗血栓」（antithrombotic）、 $\ulcorner$ 抗凝」（anticoagulant）、「冠狀動脈支架」 （coronary stent）、「圍手術期」（perioperative） $\ulcorner$ 靜脈血栓」（venous thromboembolism）、「心 血管」（cardiovascular）、「手術」（surgery） 「骨科」（orthopaedic）、「膝關節置換術」 ( knee replacement)、「髖關節置換術」 ( hip replacement ) 、「關節置換術」（joint replacement）及「關節成形術」（arthroplasty）。

資料選取 文獻回顧、原創論文和常規應用指引。

資料綜合 醫生應按動脈栓塞風險的高低而將病人分類, 從而決 定手術前後抗血栓藥物最適當的調校方案。於最近曾 植入冠狀動脈支架的病人, 包括於最近六星期內曾植 入裸金屬支架或於最近六個月內曾植入藥物塗層支架 的病人，應將手術期押後。至於已經服食亞士匹靈而 有需要作靜脈栓塞預防的病人, 醫生可調校亞士匹靈 至合適的劑量或可額外處方低分子肝素以作靜脈栓塞 預防。

結論 帶有心臟系統疾病須服食抗血栓藥物而將接受關節置 換手術的病人, 其手術前後的抗血栓藥物調校方案的 決定是基於動脈栓塞的風險及手術期間失血風險之間 的平衡。醫生應從而決定手術前後的最佳抗血栓藥物 調校方案。靜脈栓塞也是關節置換手術後常見的問 題。對於已經服食亞士匹靈病人的最佳預防靜脈栓塞 方案, 現在還未有定論。

surgeries and various prophylactic measures have been recommended. Many of these patients are already on aspirin for cardiac diseases and what constitutes optimal VTE prophylaxis strategy for this group of patients is still being debated.

We therefore set out to evaluate what might be optimal perioperative antithrombotic management for patients undergoing joint replacement surgeries. We also asked what could be the optimal strategy for the prevention of VTE in patients who are already on aspirin for the primary or secondary prevention of cardiac diseases.

\section{Search strategy and criteria}

We searched and reviewed the existing literature relevant to our questions using the MEDLINE and PubMed online database up to January 2013. Various combinations of the following keywords were used in our search: "antiplatelet", "antithrombotic", "anticoagulant", "coronary stent", "perioperative", "venous thromboembolism", "cardiovascular", "surgery", "orthopaedic", "knee replacement", "hip replacement", "joint replacement", and "arthroplasty".

\section{Patients on aspirin monotherapy}

Aspirin is an antiplatelet and non-steroidal antiinflammatory agent that works by inhibiting the synthesis of thromboxane A2, a potent stimulator of platelet aggregation by blocking the enzyme cyclooxygenase. It is widely used for primary and secondary prevention of ATE. Primary prevention is the implementation of certain interventions to prevent a healthy person from developing an illness, while secondary prevention refers to such measures to prevent progression or recurrence of a condition in a person already diagnosed to have had it.

Studies have shown that aspirin increases the risk of perioperative bleeding, but this does not translate into increased morbidity and mortality. A meta-analysis of 474 studies including orthopaedic and non-orthopaedic surgeries found that the risk of perioperative bleeding was 1.5 times higher in patients on low-dose aspirin (intake of less than 300 mg per day), but there was no significant difference in bleeding-related morbidity or mortality rates. ${ }^{4}$ In two studies of patients on low-dose aspirin therapy undergoing proximal femoral fracture surgeries, patients on low-dose aspirin were shown to have an increased likelihood of receiving blood transfusions postoperatively, yet there was no increase in bleeding perioperatively (as measured by haemoglobin decrease or perioperative blood loss). ${ }^{7,8}$ The Pulmonary Embolism Prevention (PEP) trial, a randomised study involving 17444 patients undergoing hip fracture surgeries and elective joint replacement surgeries who had low-dose aspirin started preoperatively for VTE prophylaxis, showed no difference in bleeding-related deaths between the low-dose aspirin and placebo groups. ${ }^{9}$ However, the frequency of bleeding treated with blood transfusions was $0.6 \%$ higher in the low-dose aspirin group.

On the other hand, the risk of discontinuing aspirin perioperatively is well documented. Abrupt discontinuation of aspirin is believed to produce rebound prothrombotic activity. ${ }^{10} \mathrm{~A}$ meta-analysis of 50279 patients taking low-dose aspirin for secondary prevention showed that the risk of ATE after aspirin withdrawal was 3-fold higher than in those who continued taking it. ${ }^{6}$

These studies suggest that discontinuing 
aspirin therapy should only be considered if the risk of bleeding in a particular patient outweighs that of ATE, and therefore it seems sensible to stratify patients according to their risk profile.

Indeed, in the recent 2012 guidelines published by the American College of Chest Physicians (ACCP), it is recommended that patients be stratified according to their risk of ATE. ${ }^{11}$ For high-risk patients, such as those taking aspirin for secondary prevention of ATE, it is recommended that it should be continued perioperatively. For low-risk patients, such as those taking aspirin for primary prevention of ATE, stopping aspirin 7 to 10 days before surgery is recommended, ${ }^{12}$ this being the time needed to replenish the entire platelet pool. ${ }^{13,14}$ For the latter group of patients, it was also recommended that they resume aspirin within 24 hours of surgery as soon as haemostasis is achieved.

In its guidelines on prevention of VTE for patients, the American Academy of Orthopaedic Surgeons recommended discontinuing antiplatelet therapy prior to undergoing elective hip and knee replacement surgeries. ${ }^{15}$ These recommendations were mainly based on studies showing higher postoperative blood loss and higher reoperation rates in patients undergoing coronary artery bypass grafting (CABG) surgeries. However, the guidelines did not weigh these against the risk of ATE after stopping antiplatelet therapy. It is probably more practical to follow the ACCP guidelines regarding perioperative antiplatelet therapy and stratify patients according to their ATE risks.

\section{Patients on clopidogrel monotherapy}

Clopidogrel is another type of antiplatelet agent that works by antagonising ADP receptors on platelet cell membranes, thus blocking ADP-mediated platelet aggregation. It is now commonly used as an alternative to aspirin in the primary and secondary prevention of ATE. Comparing the risk of bleeding in those on high-dose aspirin and clopidogrel, the CAPRIE trial ${ }^{16}$ (involving 19185 patients randomised to clopidogrel $75 \mathrm{mg}$ once daily and aspirin $325 \mathrm{mg}$ once daily) found that gastro-intestinal haemorrhage occurred in $2 \%$ of the clopidogrel group, and $2.7 \%$ of those on aspirin. Intracranial haemorrhage occurred in $0.4 \%$ of the clopidogrel group, and $0.5 \%$ of the aspirin group. ${ }^{16}$ To date, there are no such large-scale comparisons for low-dose aspirin versus clopidogrel.

A few studies have examined the perioperative bleeding risk of patients on clopidogrel monotherapy. One study involving patients undergoing transbronchial lung biopsy showed a higher rate of bleeding in the clopidogrel-only group (89\%) compared with the controls $(3.4 \%)$, but there were no adverse clinical outcomes as all the bleeding could be controlled endoscopically. It was recommended that clopidogrel should be stopped before transbronchial biopsy. ${ }^{17}$ Two studies involving fracture surgeries both showed no differences in the rate of bleeding complications in patients on clopidogrel and in those who were not. ${ }^{18,19}$ These results show that continuation of clopidogrel during the perioperative period may be safe in some orthopaedic surgeries.

The European Association of Cardiothoracic Surgery has published guidelines on the perioperative management of patients on clopidogrel who are about to undergo urgent cardiac surgery. The guidelines recommended stopping clopidogrel 5 to 7 days before surgery. Currently, however, there are no guidelines on clopidogrel use perioperatively for non-cardiac surgery.

More objective evidence is clearly needed to determine optimal perioperative management of patients receiving clopidogrel. Given the limited evidence currently available, it is probably sensible to stratify patients according to their risk of ATE (as for those on aspirin therapy), and then determine whether to continue or discontinue clopidogrel perioperatively.

\section{Patients on dual antiplatelet therapy}

Nowadays, it is common for patients to receive dual antiplatelet therapy with aspirin and clopidogrel. In particular, benefits of such dual therapy have been demonstrated in patients with an ACS, and those undergoing an elective percutaneous coronary intervention $(\mathrm{PCl}){ }^{20}$

Dual antiplatelet therapy is generally considered to confer a higher risk of bleeding than single antiplatelet therapy. The CURE study showed that patients who are on dual antiplatelet therapy had a $1 \%$ higher rate of bleeding complications than those on aspirin monotherapy (3.7\% vs $2.7 \%)$, irrespective of whether they underwent surgery. ${ }^{21}$ Most of the data regarding perioperative bleeding with dual antiplatelet therapy were derived from patients undergoing CABG surgeries. In these studies, it was shown that dual antiplatelet therapy increased the risk of postoperative blood loss and receipt of blood transfusions following CABG, but there were no significant differences in terms of surgical mortality or outcomes. ${ }^{22-24}$ One study showed that patients on dual antiplatelet therapy who underwent vascular, orthopaedic, and visceral surgical procedures had a higher chance of receiving a blood transfusion than controls on monotherapy ( $43 \%$ vs $39 \%){ }^{25}$

These studies suggest that dual antiplatelet therapy in the perioperative period increases postoperative bleeding rates, but does not influence postoperative morbidity or mortality.

The ACCP guidelines recommend continuing aspirin and discontinuing clopidogrel 5 days before CABG. ${ }^{11}$ However, there are no up-to-date guidelines 
for patients undergoing non-cardiac surgery. Patients receiving dual antiplatelet therapy usually have a history of ACS and a high risk of ATE; the risks of stopping both antiplatelet agents or even clopidogrel alone should be carefully balanced against the risks of perioperative bleeding. Close liaison with a cardiologist could be beneficial in devising the most suitable perioperative drug management plan for such patients.

\section{Patients having coronary artery stenting}

Coronary artery stenting is now common in patients undergoing $\mathrm{PCls}$, as it has a higher success rate and lower restenosis rate than angioplasty alone. ${ }^{26}$

There are two main types of stents that are commonly used, namely: the bare-metal stent (BMS) and the drug-eluting stent (DES). The BMS was introduced in the early 1990s and was used after PCls to prevent collapse of the coronary artery following balloon angioplasty. Stent placement causes endothelial damage of the coronary artery, the damaged tissues eventually undergo reendothelialisation, which takes approximately 3 months. ${ }^{27}$ Frequently there is excessive reendothelialisation following BMS implantation, which leads to a high in-stent re-stenosis rate. Such restenosis after BMS implantation manifests as recurrentangina and warrants repeat revascularisation in 10 to $30 \%$ of patients. ${ }^{28}$ To address this issue, in the late 1990s the DES was devised. This stent is capable of preventing neointimal proliferation by releasing antiproliferative agents. ${ }^{28}$ This has decreased the need for target lesion revascularisation by as much as $75 \%{ }^{29}$ The downside is that it also delays the reendothelialisation process and thus lengthens the time of exposed stent struts, which act as a potent nidus for stent thrombosis. ${ }^{30}$

Stent thrombosis is a platelet-mediated process on exposed stent struts that lead to progressive platelet activation, aggregation, and eventually thrombus formation. Both BMS and DES are prone to stent thrombosis prior to re-endothelialisation of the coronary arteries, which usually occurs within the first month. ${ }^{31}$ Thus, in the vast majority of cases dual antiplatelet therapy is prescribed early after stenting to prevent stent thrombosis during the vulnerable period. Late (1 month to 1 year after stenting) and very-late (more than 1 year after stenting) stent thrombosis is more common with DES use due to delayed re-endothelialisation and/or premature discontinuation of antiplatelet therapy. ${ }^{32,33}$ Furthermore, the prothrombotic and proinflammatory effects of surgery may predispose the coronary circulation to thrombosis, both at the site of stent placement and at other atherosclerotic lesions. ${ }^{34,35}$ Thus, there is a high risk of perioperative complications following withdrawal of antiplatelet therapy in patients with recently implanted stents, with studies showing that in these patients the mean perioperative mortality rates are as high as 20 to $40 \% .^{36-38}$ It has therefore been recommended that patients with recently implanted stents should continue dual antiplatelet therapy in the immediate perioperative period.

Furthermore, the ACCP has also recommended deferring elective surgery for at least 6 weeks after placement of a BMS and at least 6 months after placement of DES. In patients requiring urgent surgery within this time frame, the guidelines recommend that dual antiplatelet therapy should be continued perioperatively. ${ }^{11}$ The American Heart Association has also published guidelines in 2007 recommending deferment of elective surgery until at least 4 to 6 weeks after placement of a BMS and at least 12 months after placement of a DES. ${ }^{39}$ If procedures involving high risk of bleeding that mandate discontinuing clopidogrel must be performed within this time frame, the guidelines suggest that it is reasonable to discontinue clopidogrel 5 to 7 days preoperatively and restart the drug as soon as possible postoperatively. Newer antiplatelet agents such as prasugrel (Effient; Eli Lilly, Indianapolis, US) and ticagrelor (Brilinta; AstraZeneca, London, UK) should be stopped 7 days and 3 days, respectively before surgery. Importantly, parenteral anticoagulants such as heparin do not decrease the risk of stent thrombosis and therefore should not be considered as substitutes for antiplatelet therapy. Again, it is recommended that the best perioperative management regimen for this group of at-risk patients should be discussed with a cardiologist.

\section{Patients on anticoagulant therapy}

Indications for chronic anticoagulation of patients with cardiac diseases include atrial fibrillation and the presence of mechanical heart valves. Warfarin is the most commonly used oral agent for these patients. Newer drugs such as dabigatran (Pradaxa; Boehringer Ingelheim, Germany), rivaroxaban (Xarelto; Bayer, Leverkusen, Germany), and apixaban (Eliquis; Pfizer and Bristol-Myers Squibb, New York, US) have also been introduced into the market and have been licensed for use in patients with atrial fibrillation.

Multiple studies have shown that interruption of warfarin therapy is necessary to minimise perioperative bleeding., ${ }^{5,40-42}$ It has been shown that most surgical procedures can be performed safely if the international normalised ratio (INR) is less than 1.5.,5 It has also been reported that if the INR is between 2 and 3 on warfarin, it almost always falls to less than 1.5 within 4.8 days of the last dose. ${ }^{43}$ Therefore, ACCP guidelines recommend stopping warfarin 5 days before surgery and resuming therapy 12 to 24 hours after surgery provided there 
is adequate haemostasis. Newer anticoagulants such as dabigatran, rivaroxaban, and apixaban have shorter half-lives than warfarin, and therefore it is recommended to stop these agents 1 to 4 days before undergoing surgery; for patients taking dabigatran, the duration varies depending on renal function.

Bridging therapy is the administration of heparin while warfarin is discontinued. It is used commonly during the perioperative period, since heparin has a short duration of action and its activity is readily reversible. Nowadays, bridging therapy is mainly resorted to with $\mathrm{LMWH}$ and only very infrequently with intravenous unfractionated heparin..$^{4-46}$ The advantages of LMWH include ease of administration and the fact that it requires no monitoring, provided the patient does not have renal failure and is not pregnant.

Guidelines published by the ACCP recommend that patients on warfarin should be stratified according to their risk of developing ATE. ${ }^{11}$ Risk stratification for chronic atrial fibrillation is based on the $\mathrm{CHADS}_{2}$ score, while that for mechanical heart valves it is based on the position and type of valve (Table 1). Patients are divided into low-, moderate-, and high-risk groups. In the low-risk group, no bridging therapy is recommended after stopping warfarin. Contrarily, in high-risk patients, bridging is always recommended after stopping warfarin. For the moderate-risk group, the decision is based on the individual patient- and surgery-related risk factors. The guidelines also recommend administering the last preoperative $\mathrm{LMWH}$ dose 24 hours before surgery and for non-high-bleeding-risk surgeries (including joint replacements) resume treatment in the first 24 hours after surgery.

In the setting of total knee replacement surgeries, the conventional perioperative practice of discontinuing warfarin with or without switching to bridging therapy has recently been challenged. Concerns have been raised that bridging therapy results in rebound hypercoagulability after warfarin withdrawal, ${ }^{47-50}$ and that there are large fluctuations in INR when switching back to warfarin. ${ }^{51}$ Thus, recently there have been studies to examine whether it is safe to continue warfarin perioperatively without recourse to bridging. One retrospective study showed no increase in bleeding complications of patients who continued regular dosing of warfarin perioperatively, when compared with subjects who discontinued warfarin and switched to bridging therapy. ${ }^{51}$ Likewise, another recent retrospective study showed no increase in bleeding complications in patients who continued regular dosing with warfarin perioperatively, when compared with those not on warfarin therapy.52 Larger-scale studies are needed to justify such a change from conventional practice. Moreover, the rapid offset and onset of newer anticoagulants may obviate the need for bridging therapy. Nonetheless, more studies are needed to determine optimal perioperative management for patients taking newer drugs.

\section{Venous thromboembolism prophylaxis for patients with cardiac disease who are already on aspirin}

It is well known that patients undergoing joint replacement surgeries are at risk of developing VTE postoperatively. Many of these patients have concomitant cardiac diseases and may already be on aspirin. The optimal VTE prophylaxis for these patients is still under debate.

The PEP trial enrolled 17444 patients undergoing either total knee or hip joint replacement surgeries or hip fracture surgeries in the mid-1990s. ${ }^{9}$ The results showed that compared with patients assigned to placebo, those randomised to low-dose aspirin (160 mg once daily taken for up to 35 days post-surgery) had a $28 \%$ relative risk reduction in symptomatic deep venous thrombosis (DVT), but there was no demonstrable benefit from aspirin with respect to non-fatal pulmonary embolism (PE). The pooled results of two studies comparing LMWH against aspirin in VTE prophylaxis yielded more asymptomatic DVT in the aspirin group, with an odds

TABLE I. Guidelines published by the American College of Chest Physicians suggest risk stratification for perioperative thromboembolism

\begin{tabular}{|c|c|c|}
\hline \multirow[t]{2}{*}{ Risk stratum } & \multicolumn{2}{|c|}{ Indication for warfarin therapy } \\
\hline & Mechanical heart valve & Atrial fibrillation \\
\hline High & $\begin{array}{l}\text { - Any mitral valve prosthesis } \\
\text { - Any caged-ball or tilting disc aortic valve prosthesis } \\
\text { - Recent ( }<6 \text { months) stroke or transient ischaemic attack }\end{array}$ & $\begin{array}{l}\text { - } \text { CHADS }_{2} \text { score }^{\star} \text { of } 5 \text { or } 6 \\
\text { - Recent }(<3 \text { months) stroke or transient ischaemic attack } \\
\text { - Rheumatic valvular heart disease }\end{array}$ \\
\hline Moderate & $\begin{array}{l}\text { Bileaflet aortic valve prosthesis and one or more of } \\
\text { the following risk factors: atrial fibrillation, prior stroke } \\
\text { or transient ischaemic attack, hypertension, diabetes, } \\
\text { congestive heart failure, age }>75 \text { years }\end{array}$ & - $\mathrm{CHADS}_{2}$ score of 3 or 4 \\
\hline Low & $\begin{array}{l}\text { - Bileaflet aortic valve prosthesis without atrial fibrillation } \\
\text { and no other risk factors for stroke }\end{array}$ & $\begin{array}{l}\text { - } \mathrm{CHADS}_{2} \text { score of } 0 \text { to } 2 \text { (assuming no prior stroke or } \\
\text { transient ischaemic attack) }\end{array}$ \\
\hline
\end{tabular}


TABLE 2. An algorithm for perioperative drug management of patients with cardiac diseases*

\begin{tabular}{|c|c|c|}
\hline $\begin{array}{l}\text { Patients on the } \\
\text { following drugs }\end{array}$ & Risk stratification & Action \\
\hline \multirow[t]{5}{*}{ Aspirin } & Low & $\begin{array}{l}\text { Stop aspirin } 7-10 \text { days before surgery, resume aspirin postoperatively as soon as } \\
\text { haemostasis achieved }\end{array}$ \\
\hline & High & Continue aspirin perioperatively \\
\hline & Need VTE prophylaxis & $\begin{array}{l}\text { Usual dosage <160 mg daily: } \\
\text { (i) increase dosage to } 160 \mathrm{mg} \text { daily postoperatively up to } 35 \text { days post-surgery then resume } \\
\text { usual dosage; or } \\
\text { (ii) add LMWH in addition for } 10-14 \text { days after surgery, then switch to aspirin } 160 \mathrm{mg} \text { daily up } \\
\text { to } 35 \text { days after surgery before resuming usual dosage of aspirin }\end{array}$ \\
\hline & & $\begin{array}{l}\text { Usual dosage } \geq 160 \mathrm{mg} \text { daily: } \\
\text { (i) continue usual dosage of aspirin; or } \\
\text { (ii) add LMWH in addition to usual dosage of aspirin }\end{array}$ \\
\hline & & $\begin{array}{l}\text { Additional use of IPCD for mechanical prophylaxis of VTE postoperatively recommended for } \\
\text { all cases }\end{array}$ \\
\hline \multirow[t]{2}{*}{ Clopidogrel } & Low & $\begin{array}{l}\text { Stop clopidogrel 5-7 days before surgery, resume treatment postoperatively as soon as } \\
\text { haemostasis achieved }\end{array}$ \\
\hline & High & Continue clopidogrel postoperatively \\
\hline Dual antiplatelet & Usually high & $\begin{array}{l}\text { Consult cardiologist } \\
\text { Consider continuing aspirin, stopping clopidogrel 5-7 days before surgery and restarting } \\
\text { treatment as soon as possible post-surgery }\end{array}$ \\
\hline \multirow[t]{3}{*}{$\begin{array}{l}\text { Recent coronary stent } \\
\text { implantation }\end{array}$} & BMS & $\begin{array}{l}\text { Consult cardiologist } \\
\text { Postpone elective surgery for at least } 4 \text { weeks after stent implantation, preferably } 6 \text { weeks }\end{array}$ \\
\hline & DES & $\begin{array}{l}\text { Consult cardiologist } \\
\text { Postpone elective surgery for at least } 6 \text { months after stent implantation, preferably } 12 \text { months }\end{array}$ \\
\hline & $\begin{array}{l}\text { BMS/DES + urgent } \\
\text { surgery required }\end{array}$ & $\begin{array}{l}\text { Consult cardiologist } \\
\text { Consider continuing aspirin, stopping clopidogrel 5-7 days before surgery and restarting } \\
\text { therapy post-surgery as soon as possible }\end{array}$ \\
\hline \multirow[t]{3}{*}{ Anticoagulant therapy } & Low & $\begin{array}{l}\text { Stop warfarin } 5 \text { days before surgery } \\
\text { No bridging therapy required } \\
\text { Resume warfarin postoperatively as soon as haemostasis achieved }\end{array}$ \\
\hline & Moderate & $\begin{array}{l}\text { Stop warfarin } 5 \text { days before surgery } \\
\text { Need for bridging therapy should be based on individualised assessment } \\
\text { Consult cardiologist if in doubt }\end{array}$ \\
\hline & High & $\begin{array}{l}\text { Stop warfarin } 5 \text { days before surgery } \\
\text { Switch to bridging heparin therapy when the INR falls below the therapeutic range } \\
\text { Restart warfarin post-surgery as soon as haemostasis is achieved } \\
\text { Discontinue bridging heparin therapy when the INR is in the therapeutic range }\end{array}$ \\
\hline
\end{tabular}

* BMS denotes bare-metal stent, DES drug-eluting stent, INR international normalised ratio, IPCD intermittent pneumatic compression device, LMWH low-molecular-weight heparin, and VTE venous thromboembolism

ratio of 1.9, but there were too few patients with $\mathrm{PE}$ for meaningful comparison. ${ }^{53,54}$ These data suggest that aspirin is a feasible option for VTE prophylaxis, but overall evidence points to $\mathrm{LMWH}$ as the preferred treatment.

Recently, the ACCP has published its ninth edition guidelines for VTE prophylaxis, specifically for patients undergoing orthopaedic surgery, ${ }^{55}$ in which both low-dose aspirin and LMWH were listed as options. It was also suggested that LMWH should be preferred over other medications including aspirin for prophylaxis of VTE, regardless of whether an intermittent pneumatic device was offered as mechanical prophylaxis. One of the authors of a review article also suggested that patients already on aspirin should have LMWH added for prophylaxis of VTE. ${ }^{56}$ In the American Academy of Orthopaedic Surgeons guidelines, it was suggested that pharmacological agents and/or mechanical compressive devices should be used for the prevention of VTE. ${ }^{15}$ However, these did not provide guidance on the appropriate pharmacological agents of choice.

Based on the ACCP guidelines, LMWH should be started 12 hours or more before surgery or 12 hours or more after surgery at a prophylactic dose for at least 10 to 14 days after surgery. It was also suggested that VTE prophylaxis be extended into out-patient attendance (35 days after surgery). We therefore recommend that patients who are already on low-dose aspirin increase the dosage to at least 160 mg daily postoperatively until 35 days post-surgery and then resume the usual dosage. Alternatively, in addition to the usual aspirin treatment, prophylactic LMWH should be started 12 hours or more preoperatively, or 12 hours or more postoperatively and continued up to 10 to 14 days post-surgery and 
then switch to aspirin $160 \mathrm{mg}$ daily till 35 days postsurgery before resuming the usual dosage.

\section{Discussion}

The perioperative management of patients with cardiac diseases on antiplatelet or anticoagulant therapy undergoing joint replacement surgeries is based on a delicate balance between the perceived risk of ATE and/or VTE and the perceived risk of perioperative bleeding. Table 2 summarises the perioperative drug management approach to this group of patients. Patients should be stratified according to their risk of developing ATE to select the most appropriate perioperative antiplatelet or anticoagulant regimen. For low-risk patients, it is recommended that antiplatelet therapy and anticoagulant therapy be discontinued before surgery and resumed as soon as possible thereafter, provided there is adequate haemostasis. For high-risk patients, antiplatelet therapy should be continued; bridging therapy should be considered for those on anticoagulants. Elective joint replacement surgeries should be deferred for patients who have had recent implantation of coronary stents in receipt of dual antiplatelet therapy. For VTE prophylaxis, during the postoperative period these patients can receive either an adjusted aspirin dosage or LMWH in addition to their usual aspirin dosage.

For these patients, close liaison with a cardiologist is essential in order to devise the most appropriate perioperative drug regimen, especially for those whose ATE risk may be difficult to determine.

\section{Declaration}

No conflicts of interest were declared by authors.

\section{References}

1. Jenkins PJ, Clement ND, Hamilton DF, Gaston P, Patton JT, Howie CR. Predicting the cost-effectiveness of total hip and knee replacement: a health economic analysis. Bone Joint J 2013;95-B:115-21. cross ref

2. Salihu HM, Bonnema SM, Alio AP. Obesity: What is an elderly population growing into? Maturitas 2009;63:7-12. cross ref

3. Ansell J, Hirsh J, Dalen J, et al. Managing oral anticoagulant therapy. Chest 2001;119(1 Suppl):22S-38S. cross ref

4. Burger W, Chemnitius JM, Kneissl GD, Rücker G. Lowdose aspirin for secondary cardiovascular preventioncardiovascular risks after its perioperative withdrawal versus bleeding risks with its continuation-review and metaanalysis. J Intern Med 2005;257:399-414. cross ref

5. Tinker JH, Tarhan S. Discontinuing anticoagulant therapy in surgical patients with cardiac valve prostheses. Observations in 180 operations. JAMA 1978;239:738-9. cross ref

6. Biondi-Zoccai GG, Lotrionte M, Agostoni P, et al. A systematic review and meta-analysis on the hazards of discontinuing or not adhering to aspirin among 50,279 patients at risk for coronary artery disease. Eur Heart J 2006;27:2667-74. cross ref

7. Anekstein Y, Tamir E, Halperin N, Mirovsky Y. Aspirin therapy and bleeding during proximal femoral fracture surgery. Clin Orthop Relat Res 2004;(418):205-8. cross ref

8. Manning BJ, O'Brien N, Aravindan S, Cahill RA, McGreal G, Redmond HP. The effect of aspirin on blood loss and transfusion requirements in patients with femoral neck fractures. Injury 2004;35:121-4. cross ref

9. Prevention of pulmonary embolism and deep vein thrombosis with low dose aspirin: Pulmonary Embolism Prevention (PEP) trial. Lancet 2000;355:1295-302. cross ref

10. Beving H, Zhao C, Albåge A, Ivert T. Abnormally high platelet activity after discontinuation of acetylsalicylic acid treatment. Blood Coagul Fibrinolysis 1996;7:80-4. cross ref

11. Douketis JD, Spyropoulos AC, Spencer FA, et al. Perioperative management of antithrombotic therapy: antithrombotic therapy and prevention of thrombosis, 9th ed: American College of Chest Physicians Evidence-Based Clinical Practice Guidelines. Chest 2012;141(2 Suppl):e326S-e350S.

12. Korte W, Cattaneo M, Chassot PG, et al. Peri-operative management of antiplatelet therapy in patients with coronary artery disease: joint position paper by members of the working group on Perioperative Haemostasis of the Society on Thrombosis and Haemostasis Research (GTH), the working group on Perioperative Coagulation of the Austrian Society for Anesthesiology, Resuscitation and Intensive Care (ÖGARI) and the Working Group Thrombosis of the European Society for Cardiology (ESC). Thromb Haemost 2011;105:743-9. cross ref

13. Roth GJ, Majerus PW. The mechanism of the effect of aspirin on human platelets. I. Acetylation of a particulate fraction protein. J Clin Invest 1975;56:624-32. cross ref

14. Roth GJ, Stanford N, Jacobs JW, Majerus PW. Acetylation of prostaglandin synthetase by aspirin. Purification and properties of the acetylated protein from sheep vesicular gland. Biochemistry 1977; 16:4244-8. cross ref

15. Mont MA, Jacobs JJ. AAOS clinical practice guideline: preventing venous thromboembolic disease in patients undergoing elective hip and knee arthroplasty. J Am Acad Orthop Surg 2011;19:777-8.

16. CAPRIE Steering Committee. A randomised, blinded, trial of clopidogrel versus aspirin in patients at risk of ischaemic events (CAPRIE). CAPRIE Steering Committee. Lancet 1996;348:1329-39. cross ref

17. Ernst A, Eberhardt R, Wahidi M, Becker HD, Herth FJ. Effect of routine clopidogrel use on bleeding complications after transbronchial biopsy in humans. Chest 2006;129:734-7. cross ref

18. Collinge CA, Kelly KC, Little B, Weaver T, Schuster RD. The effects of clopidogrel (Plavix) and other oral anticoagulants on early hip fracture surgery. J Orthop Trauma 2012;26:56873. cross ref

19. Nydick JA, Farrell ED, Marcantonio AJ, Hume EL, Marburger R, Ostrum RF. The use of clopidogrel (Plavix) in patients undergoing nonelective orthopaedic surgery. J Orthop Trauma 2010;24:383-6. cross ref

20. Reaume KT, Regal RE, Dorsch MP. Indications for dual antiplatelet therapy with aspirin and clopidogrel: evidence-based recommendations for use. Ann Pharmacother 2008;42:5507. cross ref

21. Fox KA, Mehta SR, Peters R, et al. Benefits and risks of the combination of clopidogrel and aspirin in patients undergoing surgical revascularization for non-ST-elevation acute 
coronary syndrome: the Clopidogrel in Unstable angina to prevent Recurrent ischemic Events (CURE) Trial. Circulation 2004; 110:1202-8. cross ref

22. Chu MW, Wilson SR, Novick RJ, Stitt LW, Quantz MA. Does clopidogrel increase blood loss following coronary artery bypass surgery? Ann Thorac Surg 2004;78:1536-41. cross ref

23. Kapetanakis EI, Medlam DA, Boyce SW, et al. Clopidogrel administration prior to coronary artery bypass grafting surgery: the cardiologist's panacea or the surgeon's headache? Eur Heart J 2005;26:576-83. cross ref

24. Yende S, Wunderink RG. Effect of clopidogrel on bleeding after coronary artery bypass surgery. Crit Care Med 2001;29:2271 5. cross ref

25. Wilson SH, Fasseas P, Orford JL, et al. Clinical outcome of patients undergoing non-cardiac surgery in the two months following coronary stenting. J Am Coll Cardiol 2003;42:234 40. cross ref

26. Al Suwaidi J, Berger PB, Holmes DR Jr. Coronary artery stents. JAMA 2000;284:1828-36. cross ref

27. Ueda Y, Nanto S, Komamura K, Kodama K. Neointimal coverage of stents in human coronary arteries observed by angioscopy. J Am Coll Cardiol 1994;23:341-6. cross ref

28. Bornemann H, Prüller F, Metzler H. The patient with coronary stents and antiplatelet agents: what to do and how to deal? Eur J Anaesthesiol 2010;27:406-10. cross ref

29. Rade JJ, Hogue CW Jr. Noncardiac surgery for patients with coronary artery stents: timing is everything. Anesthesiology 2008;109:573-5. cross ref

30. Alfonso F. The "vulnerable" stent why so dreadful? J Am Coll Cardiol 2008;51:2403-6. cross ref

31. Chou S, Eshaghian S, Lamer A, Tran H, Dohad S, Kaul S Bridging therapy in the perioperative management of patients with drug-eluting stents. Rev Cardiovasc Med 2009;10:20918.

32. Jensen LO, Maeng M, Kaltoft A, et al. Stent thrombosis, myocardial infarction, and death after drug-eluting and bare-metal stent coronary interventions. J Am Coll Cardiol 2007;50:463-70. cross ref

33. Pfisterer M, Brunner-La Rocca HP, Buser PT, et al. Late clinical events after clopidogrel discontinuation may limit the benefit of drug-eluting stents: an observational study of drug-eluting versus bare-metal stents. J Am Coll Cardiol 2006;48:2584 91. cross ref

34. Diamantis T, Tsiminikakis N, Skordylaki A, et al. Alterations of hemostasis after laparoscopic and open surgery. Hematology 2007;12:561-70. cross ref

35. Rajagopalan S, Ford I, Bachoo P, et al. Platelet activation myocardial ischemic events and postoperative non-response to aspirin in patients undergoing major vascular surgery. Thromb Haemost 2007;5:2028-35. cross ref

36. Ferrari E, Benhamou M, Cerboni P, Marcel B. Coronary syndromes following aspirin withdrawal: a special risk for late stent thrombosis. J Am Coll Cardiol 2005;45:456-9. cross ref

37. lakovou I, Schmidt T, Bonizzoni E, et al. Incidence, predictors, and outcome of thrombosis after successful implantation of drug-eluting stents. JAMA 2005;293:2126-30. cross ref

38. Kałuza GL, Joseph J, Lee JR, Raizner ME, Raizner AE. Catastrophic outcomes of noncardiac surgery soon after coronary stenting. J Am Coll Cardiol 2000;35:1288-94. cross ref

39. Fleisher LA, Beckman JA, Brown KA, et al. ACC/AHA 2007 guidelines on perioperative cardiovascular evaluation and care for noncardiac surgery: executive summary: a report of the American College of Cardiology/American Heart Association Task Force on Practice Guidelines (Writing Committee to
Revise the 2002 Guidelines on Perioperative Cardiovascular Evaluation for Noncardiac Surgery) developed in collaboration with the American Society of Echocardiography, American Society of Nuclear Cardiology, Heart Rhythm Society, Society of Cardiovascular Anesthesiologists, Society for Cardiovascular Angiography and Interventions, Society for Vascular Medicine and Biology, and Society for Vascular Surgery. Circulation 2007;116:e418-99. cross ref

40. Katholi RE, Nolan SP, McGuire LB. The management of anticoagulation during noncardiac operations in patients with prosthetic heart valves. A prospective study. Am Heart J 1978;96:163-5. cross ref

41. Larson BJ, Zumberg MS, Kitchens CS. A feasibility study of continuing dose-reduced warfarin for invasive procedures in patients with high thromboembolic risk. Chest 2005;127:9227. cross ref

42. McKenna R. Abnormal coagulation in the postoperative period contributing to excessive bleeding. Med Clin North Am 2001:85:1277-310, viii. cross ref

43. White RH, McKittrick T, Hutchinson R, Twitchell J. Temporary discontinuation of warfarin therapy: changes in the international normalized ratio. Ann Intern Med 1995;122:40-2. cross ref

44. Ansell JE. The perioperative management of warfarin therapy. Arch Intern Med 2003;163:881-3. cross ref

45. Ickx BE, Steib A. Perioperative management of patients receiving vitamin $\mathrm{K}$ antagonists. Can J Anaesth 2006;53(6 Suppl):S113-22. cross ref

46. Spandorfer JM, Lynch S, Weitz HH, Fertel S, Merli GJ. Use of enoxaparin for the chronically anticoagulated patient before and after procedures. Am J Cardiol 1999;84:478-80, A10.

47. Genewein U, Haeberli A, Straub PW, Beer JH. Rebound after cessation of oral anticoagulant therapy: the biochemical evidence. Br J Haematol 1996;92:479-85. cross ref

48. Harenberg J, Haas R, Zimmermann R. Plasma hypercoagulability after termination of oral anticoagulants. Thromb Res 1983;29:627-33. cross ref

49. Palareti G, Legnani C. Warfarin withdrawal. Pharmacokineticpharmacodynamic considerations. Clin Pharmacokinet 1996;30:300-13. cross ref

50. Poller L, Thomson J. Evidence for "rebound" hypercoagulability after stopping anticoagulants. Lancet 1964;2:62-4. cross ref

51. Rhodes DA, Severson EP, Hodrick JT, Dunn HK, Hofmann AA. Discontinuation of warfarin is unnecessary in total knee arthroplasty. Clin Orthop Relat Res 2010;468:120-6. cross ref

52. Chana R, Salmon L, Waller A, Pinczewski L. Warfarin management in patients on continuous anticoagulation therapy undergoing total knee replacement. J Bone Joint Surg Br 2011;93:1497-502.

53. Graor RA, Stewart JH, Lotke PA, et al. RD heparin (ardeparin sodium) vs aspirin to prevent deep venous thrombosis after hip or knee replacement surgery. Chest 1992;102(Suppl):118S.

54. Westrich GH, Bottner F, Windsor RE, Laskin RS, Haas SB, Sculco TP. VenaFlow plus Lovenox vs VenaFlow plus aspirin for thromboembolic disease prophylaxis in total knee arthroplasty. J Arthroplasty 2006;21 (6 Suppl 2):139-43. cross ref

55. Falck-Ytter Y, Francis CW, Johanson NA, et al. Prevention of VTE in orthopedic surgery patients: antithrombotic therapy and prevention of thrombosis, 9th ed: American College of Chest Physicians Evidence-Based Clinical Practice Guidelines. Chest 2012;141(2 Suppl):e278S-325S

56. Deitelzweig SB, McKean SC, Amin AN, Brotman DJ, Jaffer AK, Spyropoulos AC. Prevention of venous thromboembolism in the orthopedic surgery patient. Cleve Clin J Med 2008;75 Suppl 3:S27-36. cross ref 